\title{
International Joint Ventures as Boundary Spanners: Technological Knowledge Transfer in an Emerging Economy
}

\section{This is a pre-print (non-publisher's document). Please cite the published article:}

Khan, Zaheer, Yong Kyu Lew, and Rudolf R. Sinkovics (2015), "International joint ventures as boundary spanners: Technological knowledge transfer in an emerging economy," Global Strategy Journal, 5 (1), 48-68. (DOI: 10.1002/gsj.1089). http://dx.doi.org/10.1002/gsj.1089

\begin{abstract}
We investigate how international joint ventures (IJVs) established in emerging economies help their local suppliers with technological knowledge transfer. Data from 50 Pakistaniowned tier 1 suppliers, three of the major assemblers and policy makers in the Ministry of Industries and Production in Pakistan is collected. Findings suggest that, in the context of the Pakistani emerging economy, IJVs can also play a critical role as the facilitators of knowledge transfer. Local suppliers are linked with their global suppliers' networks through associational learning. Social capital between the IJVs and the local component suppliers, and the IJVs' willingness to initiate a knowledge transfer dialogue amongst local and global tier 1 suppliers, are critically important factors enabling this transfer to take place.
\end{abstract}

\section{Keywords}

International joint ventures; technological knowledge transfer; boundary spanners; social capital; automotive industry; emerging economy

\section{Authors}

\section{Zaheer Khan}

Lecturer in Strategy \& International Business

University of Sheffield, UK

khan.zaheer@gmail.com

\section{Yong Kyu Lew}

Assistant Professor of International Business and Strategy

Sejong University, South Korea

yklew01@gmail.com

\section{$\underline{\text { Rudolf R. Sinkovics }(\triangle)}$}

Professor of International Business

Centre for Comparative and International Business Research (CIBER)

The University of Manchester, Manchester Business School

Booth Street West, Manchester M15 6PB, United Kingdom

Rudolf.Sinkovics@manchester.ac.uk, www.manchester.ac.uk/reseach/rudolf.sinkovics 


\title{
International Joint Ventures as Boundary Spanners: Technological Knowledge Transfer in an Emerging Economy
}

\begin{abstract}
We investigate how international joint ventures (IJVs) established in emerging economies help their local suppliers with technological knowledge transfer. Previous research has focused on multinational enterprises (MNEs) and especially IJVs established in emerging and developing countries as a source of knowledge transfer and holders of valuable knowledge stock. We collected qualitative data on 50 Pakistani-owned tier 1 suppliers, three of the major assemblers and the policy makers at the Ministry of Industries and Production in Pakistan. Our findings suggest that, in the context of an emerging economy, IJVs can also play a critical role as the boundary spanners of knowledge transfer by linking the local suppliers with their global suppliers' networks through associational learning when the suppliers in the developing countries lack absorptive capacity and have limited connectivity within the MNE's global production network. Furthermore, social capital between the IJVs and the local component suppliers, and the IJVs' willingness to initiate a knowledge transfer dialogue amongst local and global tier 1 suppliers, are critically important factors enabling this transfer to take place. Interestingly, this knowledge transfer from MNEs to local component suppliers through IJVs is more actively facilitated when the local suppliers have low connectivity within the MNEs' network. The mere establishment of IJVs does not automatically lead to technological knowledge transfer to the wider host networks, which demonstrates how IJVs act as boundary spanners between their parent's network and the host country's poorly connected network. IJVs play their role as boundary spanners in the transfer of knowledge from the developed country's network to the developing country's network in order to give the developing country's suppliers the opportunity to use this knowledge to develop their technological capabilities.
\end{abstract}

\section{Keywords}

International joint ventures; technological knowledge transfer; boundary spanners; social capital; automotive industry; emerging economy 


\section{International Joint Ventures as Boundary Spanners: Technological Knowledge Transfer in an Emerging Economy}

\section{INTRODUCTION}

The impacts of multinational enterprises (MNEs) on host countries have been studied since the 1960s (Hymer, 1960). Policy makers in developing economies have put attracting foreign direct investment (FDI) at the top of their policy menus, in the hope that investment by MNEs will bring much-needed capital, sophisticated and updated technological knowledge, production methods, marketing techniques, and tacit and codified managerial know-how to local firms (World Bank, 1993).

According to Meyer and Sinani (2009), local firms view FDI as both competition and a source of advanced technologies and managerial knowledge. Keeping in mind these benefits, the Government of Pakistan has embarked upon liberalization, deregulation and privatization programs, and developed sector-specific policies for FDI (e.g. Pakistan Board of Investment, various publications). The World Bank (2010) has recently recognized Pakistan as the 83rd most business friendly country in the world in its annual 'ease of doing business' index.

The transfer and receipt of technological knowledge is of fundamental concern to scholars investigating how firms and local (and national) economies grow in terms of technological knowledge, which functions as a base for developing sustainable competitive advantage (Lyles and Salk, 1996; Tsai, 2001; Zahra, Ireland, and Hitt, 2000). Several scholars have suggested that recipient firms can gain long-term benefits from technology transfer (Dyer and Nobeoka, 2000; Dyer and Singh, 1998; Gupta and Govindarajan, 2000; Simonin, 1999; Szulanski, 1996; Zander and Kogut, 1995). On the other hand, scholars have acknowledged that 
it is critical that the technology transfer be effective in this highly competitive and uncertain environment (Bhagat, Harveston, and Triandis, 2002; Hansen, 2002; Pérez-Nordtvedt, Kedia, Datta, and Rasheed, 2008).

The entry of MNEs also contributes to the development of underdeveloped supply chains in the host countries through their sourcing behaviors. Recently, researchers have documented that the entry of MNEs can be beneficial for local suppliers because they transfer technology to them, which is in the interests of MNEs as it creates vertical linkages (Blalock, 2001). However, one aspect that still requires better understanding is how MNEs influence the development of local firms, again mainly through their local sourcing behaviors (see e.g. Javorcik, 2004; Moran, 2005).

MNEs often prefer the establishment of international joint ventures (IJVs) as a governance vehicle when they decide to set up operations in emerging and developing economies, in the hope that equity partnerships will help with the transfer of technological knowledge. For example, China, India, and Pakistan have all, from time to time, seen IJVs used as the preferred mode of entry. In this respect, extant international business (IB) research has focused on knowledge transfer between the joint ventures' partners, reverse knowledge transfer from subsidiaries/IJVs to headquarters, or knowledge transfer from parents to IJVs in emerging and developing markets. Furthermore, previous research has focused on MNEs, and especially IJVs, established in emerging and developing countries as a source of knowledge transfer and as the holders of valuable knowledge stock (Beamish, 1993; Child and Yan, 2001; Lyles and Salk, 1996). However, in the context of emerging countries, these IJVs can also play a critical role in facilitating knowledge transfer beyond their own boundaries to their local network suppliers when those suppliers lack absorptive capacity and have limited connectivity within the MNE's 
global production network. This is one of the crucial roles of IJVs that, so far, the extant literature has downplayed.

Little research has focused its attention beyond the IJVs' boundaries to their local suppliers in the developing and emerging economies (Zhao, Anand, and Mitchell, 2005). As Easterby-Smith, Lyles, and Tsang (2008, p.677) suggest, "transferring knowledge between organizations brings more complexity because of the multifaceted nature of the boundaries, cultures, and processes involved. It is therefore an interesting domain for further theoretical investigation". In addition, research has demonstrated that accessing knowledge from across boundaries is an important contributor to innovation and organizational performance (Cohen and Levinthal, 1990; Hansen, 1999; Tsai, 2001). Indeed, since heterogeneous knowledge resides across firm, national, and international boundaries, individuals involved in moving knowledge across these boundaries might struggle to find a common ground to facilitate the transfer and integration of knowledge, due to social and cultural differences, a lack of common understanding, and coordination issues (Bechky, 2003; Mors, 2010).

Research in the field of innovation has acknowledged the key role of boundary spanners within and across organizations in the process of innovation (Allen, 1977; Henderson and Clark, 1990; Tushman, 1977). Similarly, research in the area of cross-unit knowledge transfer has noted the important role played by individuals who maintain close connections with their colleagues in different organizational units in facilitating such transfer (Allen and Cohen, 1969). Despite these contributions, empirical support is scarce and often mixed about the success of boundary spanners. One line of research has suggested they play a positive role, pointing out that organizational units with boundary spanners are more productive (Ancona and Caldwell, 1992; Hansen, 1999; Tushman and Katz, 1980). Other researchers note a negative role in the transfer of 
knowledge within organizations (Cross, Nohria, and Parker, 2002; Gould and Fernandez, 1989), either because of the boundary spanners' desire to keep their power and influence or because they do not want to invest the time and effort needed to transfer knowledge efficiently. So far, research has mainly looked at the role of boundary spanners within organizations (e.g. Fleming and Waguespack, 2007; Leifer and Delbecq, 1978; Marrone, Tesluk, and Carson, 2007; Tushman and Katz, 1980; Zhao and Anand, 2013). In this paper, we extend this line of reasoning to the context of IJVs. We consider that IJVs established in emerging economies may overcome barriers to knowledge transfer due to their position in their parents' networks. They can play vital roles as boundary spanners by linking local suppliers with these networks. This argument is also in line with the recent findings of Tortoriello and Krackhardt (2010), suggesting there are no advantages associated with bridging ties per se, but that the effects are contingent upon the nature of the ties forming the bridge (Phelps, Heidl, and Wadhwa, 2012). These boundary spanners may then facilitate the formation of a shared vision and common goals by mediating and mitigating opportunism and self-interest amongst network partners, and especially those who are less connected within the central network.

In this paper, we investigate specifically how IJVs established in the automotive industry in Pakistan have helped their local component suppliers by transferring technological knowledge ${ }^{1}$. This question is crucially important in the context of emerging and developing economies, for several reasons. Firstly, it is important for local firms in emerging and developing economies to move beyond the boundaries of the IJVs to the wider host country context. Secondly, local component suppliers constitute an important part of the local supply chain of the automotive industry. However, it seems that the extant IB literature has not documented very

The three IJVs are OEM automotive assemblers and the terms 'assembler' and 'IJV' will be used interchangeably in this paper. 
well whether IJVs have helped the local suppliers to link up with their established network suppliers so as to become a part of their global production networks. From the perspective of the host governments of emerging and developing economies, connecting the unconnected through associational learning may be a justification for giving incentives (e.g. tax holidays and the repatriation of profits to foreign investors) to MNEs. This follows Meyer's (2004, p.264) suggestion, that "future research ought to prioritise the study of individual interactions of a multinational firm and a local agent or firm". Thus, the focus of this study is on a relatively understudied context: the role of IJVs in transferring technological knowledge to their local suppliers in Pakistan's automotive industry.

The rest of the paper is organized as follows. In the second section, we discuss the conceptual background of this paper. Then, we discuss our research context and methods. After that, we present our findings and discuss the contributions, implications, and limitations of the research. Lastly, conclusions are presented.

\section{CONCEPTUAL BACKGROUND}

\section{The knowledge-based view}

The traditional resource-based view sees a firm as a bundle of difficult-to-imitate resources and distinctive capabilities. The deployment and subsequent management of these resources and capabilities gives the firm a competitive advantage in the market. Similarly, the knowledgebased view (KBV) considers the firm to be a collection of knowledge, as knowledge is embedded in resources (Grant, 1996; Nonaka and Takeuchi, 1995). KBV scholars argue that knowledge is the single most important organizational resource, and ultimately leads to the development of distinctive capabilities and competitive advantage (Bhagat et al., 2002; Teece, Pisano, and Shuen, 1997). As Grant (1996, p.375) points out, "knowledge has emerged as the 
most strategically significant resource of the firm". The acquisition of knowledge and skills gives a firm a competitive advantage, and through them the firm is able to innovate, developing new products, processes, or services, or possibly improving the existing ones to make them more efficient and effective (Nonaka, Toyama, and Konno, 2000).

The strategic importance of knowledge as a resource is particularly prevalent in technology-intensive industries (Barney, 1986; Grant, 1996). For the automotive industry in particular, the most important firm characteristic is the ability to generate new knowledge alongside its proprietary knowledge. In a similar vein, Kogut and Zander (1992) discuss the notion of 'combinative capabilities', which consist of a firm's ability to use the existing stock of knowledge to create new knowledge, as well as a firm's ability to utilize current knowledge. As Grant (1996, p.384) suggests, "knowledge is the preeminent resource of the firm". In a similar context, Liebeskind (1996) posits that knowledge is perhaps the most important asset that a firm possesses. Thus, the KBV regards the firm as a stock of knowledge assets that it can utilize to create additional value (Grant, 1996).

Technology can be defined in many ways, but researchers usually refer to the words 'technology' or 'technological knowledge' as “a way of doing something” (Nelson and Winter, 1982, p.60) and "a collection of physical processes that transforms inputs into outputs and knowledge and skills that structure the activities involved in carrying out these transformations" (Kim, 1997, p.4). The prior literature has discussed the nature of technology, noting that it typically takes two main forms, i.e., 'explicit' and 'tacit' (Polanyi, 1962). Sometimes, these two forms are referred to as 'hard' and 'soft' technology. Explicit technology refers to a particular form of technology that can be codified (e.g., a production manual, specifications, and drawings), whereas tacit technology/skills are difficult to codify. Prior research suggests that the 
tacit characteristics of technological knowledge create several challenges for organizations attempting to transfer this type of knowledge. For the transfer of tacit knowledge, the sender of the knowledge and the recipient are required to engage in close interaction and to have close interorganizational contact (Cook and Brown, 1999). Previous research has also discussed the imperative of the recipient's level of absorptive capacity (Cohen and Levinthal, 1990; Lyles and Salk, 1996; Park, 2011) for the acquisition of knowledge from the sender. Within the remit of $\mathrm{KBV}$, several scholars have suggested the important role of individual actors acting as boundary spanners, in harnessing knowledge management within organizations (e.g. Cross and Parker, 2004; Davenport and Prusak, 1998; Hargadon and Sutton, 1997; Pawlowski and Robey, 2004; Swan and Scarbrough, 2001). However, the literature on boundary spanners is mixed, and has focused on the individual level of analysis, thus theorizing that the effects of organizational-level boundary spanners are limited (e.g. Mudambi and Swift, 2009). In the next section, we elaborate on the roles of the boundary spanners at different levels.

\section{Boundary spanner}

In organization studies, drawing an organizational boundary is meritorious as organizational boundaries help to distinguish an organization from the environment in which it operates (Allen and Cohen, 1969; Kast and Rosenzweig, 1970; Starbuck, 1976; Utterback, 1971). Through this demarcation, the organization can develop a protective mechanism against environmental stresses and risks (Miller, 1972), control the flow of information and materials between the organization and its environment, and define organizational tasks. Boundary spanners are individuals who perform multiple roles at the intersection between an organization and its environment (e.g. boundary-spanning employees) (Aldrich and Herker, 1977). These individuals are deeply involved in the boundary-spanning process of filtering the information flow between 
boundaries (Aldrich and Herker, 1977; Patriotta, Castellano, and Wright, 2013; Tushman and Scanlan, 1981), and represent the ideas of organizations (Friedman and Podolny, 1992). In particular, individual actors such as key managers play boundary-spanning roles in the innovation process within an organization (e.g. Carlile, 2002; Levina and Vaast, 2005; Rosenkopf and Nerkar, 2001; Tushman and Scanlan, 1981). As a result, most research on boundary spanners has focused on individuals' roles within an organization (e.g. Fleming and Waguespack, 2007; Leifer and Delbecq, 1978; Marrone et al., 2007; Tushman and Katz, 1980; Zhao and Anand, 2013).

However, the role of boundary spanners is also critically important in the intra and interfirm knowledge transfer process. With regard to the knowledge creation and transfer process, boundary spanner studies have investigated their key roles in innovation creation within an organization (Henderson and Clark, 1990; Tushman, 1977). For example, boundary-spanning employees maintain close connections with their colleagues, and thus facilitate cross-unit knowledge transfer within an organization (Zhao and Anand, 2013). However, empirical support is scarce and often mixed regarding whether boundary spanners play a positive role in the process of knowledge transfer (Ancona and Caldwell, 1992; Hansen, 1999) or not (Cross et al., 2002; Gould and Fernandez, 1989). The mixed results might be due to the boundary spanners' desire to keep their power and influence, their unwillingness to invest the time and effort needed to transfer knowledge efficiently, and/or the complexity of knowledge needing to be transferred. In the field of international business, individuals termed as biculturals, expatriates, inpatriates, and global managers are being dubbed as knowledge transfer intermediaries within the networks of MNEs and their subsidiaries (see e.g., Bell and Harrison, 1996; Brannen and Thomas, 2010; Johnson and Duxbury, 2010; Kostova and Roth, 2003; Patriotta et al., 2013; Reiche, 2011; 
Reiche, Harzing, and Kraimer, 2008). Taken together, the literature on boundary spanners has mainly been investigated at the individual level, but the role of boundary spanners at the interorganizational level has rarely been investigated, particularly in the context of globally dispersed knowledge transfer. In this paper, the notion of boundary spanners is extended to the context of IB and interorganizational relationships. More specifically, we link the above literature to the IJVs and their networks, including such entities as local suppliers, the IJV headquarters, and its global knowledge network. We take the view that IJVs can serve as boundary spanners between knowledge- and network-constrained local suppliers in developing economies, and the knowledge- and network-abundant MNE headquarters. These boundary spanners can also help to develop social capital between unconnected actors. Next we discuss the importance of social capital in interfirm knowledge transfer.

\section{Social capital}

In the context of inter-firm knowledge transfer, a clear understanding of social capital theory is important. The underlying principles of this theory help us to develop a better understanding of the role the IJVs play in transferring technological knowledge to their local component suppliers in the context of Pakistan's automotive industry.

Social capital theory encapsulates the idea that social relations are key valuable assets due to the access to resources that is generally available through social bonds (Granovetter, 1992). Nahapiet and Ghoshal (1988), for instance, propose three underlying dimensions of social capital: structural, cognitive, and relational. They argue that the structural aspect is related to social capital arising from the structural configuration, social ties, diversity, trusting relationships, shared values centrality, and boundary-spanning roles of network participants (Tsai and Ghoshal, 1998). The cognitive aspect refers to the resources that provide parties to the 
relationship with shared representations, interpretations, and systems of meaning. Finally, Nahapiet and Ghoshal (1998) point out that the relational dimension refers to personal relationships that develop through a history of interactions, leading to trust, a sense of obligation, and reciprocity between the parties.

The impact of social capital on knowledge transfer performance has been studied by various scholars, mainly in the context of joint venture partners. For example, scholars in the field of organizational research posit that alliance partners' investment in interfirm knowledgesharing routines results in a firm's value creation (Dyer and Singh, 1998; Grant, 1996). In the automotive industry, knowledge shared by the assemblers may include both factual knowledge such as the sharing of production schedules (Kogut and Zander, 1992), and more tacit, sticky, and difficult-to-codify knowledge such as know-how. The latter type of knowledge is difficult to transfer either within or across organizations (Szulanski, 1996). However, close interactions between the employees of the firms concerned act as an effective conduit for the transfer or learning of tacit know-how (Marsden, 1990; von Hippel, 1988). In this paper, we focus on two types of social capital (structural and relational) as the IJV partners that are established in our research context have developed cognitive capital such as shared norms and congruent goals so as to retain their social ties in the automotive parts industry (Inkpen and Tsang, 2005; Kim, Oh, \& Swaminathan, 2006).

\section{Structural capital}

Structural capital involves the patterns and configurations of relationships and linkages among the organizations concerned (Inkpen and Tsang, 2005). Socially embedded relations facilitate access to useful knowledge and resources, and increase and enhance knowledge transfer (Reagans and McEvily, 2003). Relational embeddedness is an important factor in the sharing of 
knowledge by network partners (Uzzi, 1997). Moreover, due to structural inertia, structural ties between socially embedded network partners hinder changes in network partnerships (Kim et al., 2006). Thus, research in the fields of IB and organization have recognized the pivotal role of knowledge sharing in the building of a firm's organizational capabilities, whether obtained through interfirm ties in general (Ahuja, 2000; Gulati, 1999), or knowledge sharing with key suppliers more specifically (Dyer and Hatch, 2006; Dyer and Nobeoka, 2000). For instance, Dyer and Nobeoka (2000) investigate institutionalized routines established between highperforming suppliers and reciprocal knowledge sharing between the suppliers from developed countries. ${ }^{2}$ Partners' interactions within their network structure allow them to exchange knowledge with each other frequently. Furthermore, structural capital between international network partners contributes towards enhancing organizational performance (Malik, 2012).

\section{Relational capital}

Relational capital refers to the nature of the relationships themselves, and the assets that are rooted in those relationships (Tsai and Ghoshal, 1998). Relational capital resides in network relationships as a form of socialized capital within a network structure (Kale, Singh, and Perlumutter, 2000; Liu, Ghauri, and Sinkovics, 2010). Research on relational capital emphasizes its role in social exchanges between trustworthy network partners (Faems, Janssens, Madhok, and van Looy, 2008). Particularly, previous studies point out the importance of the strength of relations and trust (see e.g. Boersma, Buckley, and Ghauri, 2003; Madhok, 1995; Ring and van de Ven, 1994). High levels of trust in network relationships mean that network partners need

In the current study, our research interests are IJVs established in a developing economy, and their networks. In our research context, the automotive parts industry in Pakistan, the institutionalized routines are not established between the global tier 1 suppliers and the local underdeveloped suppliers ( $c f$. Dyer and Noboka, 2000). So, in this case, knowledge has to come from the global suppliers and there is very little that the local suppliers can offer to the global tier 1 suppliers. Hence, the boundary spanner role becomes important to facilitate the transfer of international knowledge to host markets. 
fewer protective knowledge exchange deterrence mechanisms (Gulati and Nickerson, 2008) as "exchange obligations promote trust, [and] special mechanisms exist to perpetuate obligations and thus strengthen bonds of indebtedness and trust" (Blau, 1964, p.99). Thus, trust "reflects the belief that a partner's word or promise is reliable and that a partner will fulfill its obligations in the relationship" (Inkpen, 2000, p.1027). In the context of international knowledge transfer, relational capital (e.g. trust) enables knowledge transfer since it increases the partners' willingness to commit to helping each other to understand new knowledge (Cullen, Johnson, and Sakano, 2000; Lane, Salk, and Lyles, 2001; Szulanski, Cappetta, and Jensen, 2004).

The discussion above highlights the important roles of knowledge in the development of competitive advantage, and boundary spanners in linking the organization with its environment, and in developing social capital between actors. However, there is little research with an explicit focus on organizational level boundary spanners in the transfer of global knowledge to local firms based in the emerging economies. In the following section, we discuss our research context and methods in order to explore the role of IJVs as boundary spanners of technological knowledge transfer to emerging economies' firms.

\section{RESEARCH CONTEXT AND METHODS}

The empirical research setting of this paper is the automotive parts industry in Pakistan. We chose this context for a number of reasons. Firstly, the industry manufactures products consisting of a large number of different components, requiring long supply chains. MNEs' investment in assembly plants may have a significant impact on local component suppliers in this industry. Secondly, the automotive parts industry is considered a key industry in Pakistan, due to its effects on the value chains of other industries through backward and forward linkages. Next, in Pakistan, this industry is dominated by three major Japanese assemblers (Toyota, Honda, and 
Suzuki) that have brought substantial FDI to Pakistan's automotive industry. These three assemblers are expected to play a vital role in the underdeveloped supply base and in the development of the engineering and design capabilities of the local component suppliers. The three IJVs control $95-98 \%$ of the local market share. In contrast, there are around 800 organized and 1,200 unorganized component suppliers.

We focus on the organized tier 1 Pakistani suppliers segment because the organized suppliers are the registered suppliers of original equipment manufacturers (OEMs) operating in Pakistan's automotive industry, and these suppliers deal directly with the OEMs, whereas unorganized suppliers supply parts for the replacement (after-sales) market. The structure of Pakistan's automotive industry is unique, and very different from those in advanced economies such as in Europe and the US (see Figure 1). In Western markets, tier 1 suppliers are responsible for managing and working with tier 2 and tier 3 suppliers, and OEMs mainly deal directly with their global tier 1 suppliers (Sturgeon, Van Biesebroeck, and Gereffi, 2008). However, the assemblers in Pakistan (i.e., the three Japanese IJVs) separately and directly work with both global tier 1 suppliers and local tier 1 suppliers; there are limited opportunities for local tier 1 component suppliers to collaborate directly with global tier 1 suppliers. Because of the unique industry structure, Pakistani tier 1 suppliers have difficulties in learning from advanced global tier 1 suppliers through direct technological knowledge transfer. Pakistan's automotive industry was formed in the 1950s and has gone through various phases of progress, as shown in Table 1. The industry has technical tie-ups and IJVs with the leading MNEs. The three major IJVs are between Japanese automotive assemblers and Pakistani partners. Table 2 lists these IJVs and their major products. 
Insert Figure 1, Table 1 and Table 2 about here

\section{Interviews}

We conducted semi-structured interviews with the top 50 Pakistani tier 1 suppliers, the three main IJVs (automotive assemblers) and the Ministry of Industries and Production (MOI\&P). We acknowledge that there is already sufficient extant quantitative research on the knowledge transfer taking place within the IJV context (Dhanaraj, Lyles, Steensma, and Tihanyi, 2004; Lyles and Salk, 1996; Tsang, Nguyen, and Erramilli, 2004). However, research is limited when it comes to our context and the current theorizing of organizational boundary spanners and their role in the transfer of globally dispersed knowledge. Therefore, we selected a qualitative methodology to build our understanding about the role IJVs play in the transfer of international knowledge down to their host country's networks of local suppliers. Our approach is also in line with the current research in the field of IB, wherein the use of qualitative methods is emphasized (Birkinshaw, Brannen, and Tung, 2011; Doz, 2011; Marschan-Piekkari and Welch, 2004). As Doz (2011, p.588) notes, "qualitative research methods offer the opportunity to help move the field forward and assist in providing its own theoretical grounding". In contrast, we based our study on the KBV and boundary-spanning theories. We also interviewed multiple informants from the IJVs, local suppliers, and officials from the MOI\&P. The relevant theories and multiple sources of data help develop a broad understanding about the phenomenon under study. The sampling procedure was as follows.

Firstly, the Pakistan Association of Automotive Parts and Accessories Manufacturers (PAAPAM) and the MOI\&P were used as the basis for the sampling frame. All component 
suppliers with at least 100 employees and a direct business relationship with one of the three assemblers/IJVs were included as randomly selectable cases for this research. Through this procedure, 200 suppliers were identified, and an introductory letter about the research was sent to the president/owner of each one, asking them to provide the names of the main company employee directly responsible for the company's supply relations with the automotive assembler. At this stage, 75 component suppliers expressed a willingness to participate in the study and provided the contact details of a relevant manager. A personalized letter explaining the nature of the research was then sent to these managers. The managers were told that they would receive a summary of the research and that their company information would be kept confidential. Out of these 75 managers, only 50 were eventually interviewed due to time and logistical reasons. Brief interviewee profiles are shown in Table 3 . There are around 800 suppliers operating in the automotive industry in Pakistan, so in order to overcome the self-selection bias of the sample, we adopted the random method of sampling to prepare the list of suppliers. However, for the interviews, purposive sampling was used; we interviewed only those suppliers who worked directly with the three assemblers.

The interviews addressed questions concerning the IJVs' willingness to transfer technology and develop local suppliers' capabilities, the local suppliers' capabilities themselves, local and global tier 1 suppliers' collaborations, interactions with global suppliers, the role of the assemblers in linking local and global suppliers, the motivations for partnerships with the international suppliers, how the IJVs negotiated the global and local suppliers' knowledge transfer collaborations, types of technology being transferred to the local Pakistani suppliers, types of parts being sourced locally as opposed to globally, the knowledge transfer process, social ties between the suppliers and the assemblers, issues related to resolving conflict, and 
transfer mechanisms. These questions were used as a guide only, and ad hoc questions were also added and addressed as they arose during the course of the interviews. We also interviewed policy makers from the MOI\&P, because we wanted to have multiple perspectives about the technology transfer going from the IJVs to their local Pakistani suppliers and the policy responses on local content issues within the automotive industry of Pakistan, IJVs' help in developing local suppliers' capabilities, and the future trends in the local market. We also deemed it necessary to include the policy makers in our interviews, as we wanted to know what the government response was to the technology transfer taking place through these Japanese assemblers.

We conducted these interviews from March 2008 to November 2009. The interviews were conducted in English or in Urdu, the Pakistani national language. The interview guide was prepared in both English and Urdu and during the interviews we gave our interviewees the option to be interviewed in English or Urdu. It is worth noting here that the majority of the interviewees were comfortable with both languages. However, some preferred to be interviewed in their national language. The interviewees were encouraged to share deep insights about the technology transfer taking place, from the three assemblers to their firms, and the role of the assemblers in linking them with their global suppliers. The Urdu language interviews were transcribed into Urdu to keep the richness of the data, and were then translated back into English. The Urdu language translations were compared with the interviews conducted in English and no major problems were noticed in the consistency of these interviews with those conducted in English.

Insert Table 3 about here 


\section{Data analysis}

The interview data were coded and analyzed using the suggestions of Miles and Huberman (1994). This process consisted of coding the data from each individual interview to identify major themes and categories. An organizational anthropologist and a management scientist helped us by auditing and cross-checking the coding scheme. We used the help of these independent auditors to ensure our research themes were consistent and understood by these auditors, across our sample. This also ensured that we were not reporting any pre-existing bias of the researchers. In addition, both these auditors possess an excellent understanding of the automotive industry and the general business environment of Pakistan. Thus, their experience enhances the dependability of our findings. Through this process, the issues of confirmability and dependability were also tackled (e.g. Kolbe and Burnett, 1991; Sinkovics, Penz, and Ghauri, 2008). The auditing consisted of verifying the process (the steps followed by the coder) and the product of the data coding. There was some level of disagreement during the audit process, which was removed by revisiting the interview notes and, in some cases, revising the categories. Table 4 illustrates the key themes identified through template analysis. The first column shows the identified themes of 'boundary spanner' and 'social capital', and the third column provides some illustrative interview excerpts related to these themes.

Insert Table 4 about here 


\section{FINDINGS}

\section{IJVs as boundary spanners of technological knowledge transfer}

The interview data indicate that the three IJVs have not only transferred components technology of a low-to-medium complexity to the Pakistani tier 1 suppliers, but in some cases have also acted as boundary spanners of technological knowledge transfer to those local suppliers by linking them up with their international tier 1 suppliers, based on their social ties and long-term trust.

Our results suggest that the three IJVs have provided assistance by linking some of the Pakistani local suppliers to first-tier suppliers from their networks, based in Japan. The suppliers have received technological knowledge through technical assistance/collaboration agreements, and the assemblers have played a major role in initiating dialogues and facilitating this process with their first-tier suppliers.

Some of the comments made by one of our interviewees were as follows:

“... either we, the local component suppliers, gain technical expertise related to product, process and management know-how through our own experience or we can enter into a technical collaboration with the Japanese suppliers, but in the latter case our costs will be much higher and we will always be depending on the provider of that technological knowledge. Our clients are willing to initiate the technology transfer dialogue with their first-tier suppliers in Japan." [Director of Planning and Operations - Component Supplier 22]

The data indicate that personal experiences are important in developing firm-level capabilities, and that capabilities can also be developed by establishing linkages with external organizations, in this case the transnational tier 1 suppliers. The suppliers' managers suggested that they get knowledge of low-to-medium complexity from their assemblers and, if they wanted to develop complex parts, for example engine parts, transmission and electrical parts, then the assemblers would want the local Pakistani suppliers to enter into joint venture arrangements with their (the assemblers') transnational 
tier 1 suppliers. The managers pointed out that the transnational tier 1 suppliers charged higher prices in order to set up the joint ventures with the Pakistani suppliers and, in most cases, these transnational tier 1 suppliers were reluctant to enter into joint venture arrangements with the local Pakistani suppliers because of the fear of losing their competitive advantage. The data indicate that, in order to overcome this reluctance on the part of the transnational tier 1 suppliers, the IJVs performed their role as boundary spanners, as the knowledge has to come from their transnational suppliers and they facilitate this international knowledge transfer to the local Pakistani suppliers in order to get particular parts developed in Pakistan. As one of the interviewees mentioned:

"Our company makes electrical parts for our client and we have joined together, I mean in a technical collaboration, with a leading Japanese electrical component supplier. This process was initiated by our client (the assembler). The assembler played the role of initiator and facilitator in this transfer. All our communications and agreements took place with the help of our client." (Manager of Product Development - Component Supplier 19)

The above quote seems to suggest that the IJVs have been involved in moving knowledge from international suppliers to their local Pakistani suppliers, and not only have they initiated the dialogue but they have helped with the entire process leading up to the signing of the collaboration agreement between the parties. The boundary spanner role becomes important in this context, as the local suppliers in developing economies are not well-connected with the global production networks of these auto assemblers, and this role also overcomes issues of modularity, by helping the developing countries' suppliers to increase their product-related learning capabilities. Research has pointed out that increasing modularization of components means that limited learning opportunities are available for local suppliers, and especially those based in developing economies (Breznitz and Murphree, 2011; Gereffi, Humphrey, and Sturgeon, 2005; Giuliani, Pietrobelli, and Rabellotti, 2005; Humphrey and Memedovic, 2003; Quadros, 2004; Sturgeon and Florida, 2005). The boundary spanner role played by IJVs could create learning opportunities between the transnational tier 1 suppliers and the suppliers from developing countries. This view was echoed by another supplier:

"Our local component buyers (the assemblers) have played an important role in linking us with their principal's networks in Japan. For instance, with the help of our 
assemblers, we were able to form technical collaborations with one of the leading Japanese suppliers. Without this assembler's help, we wouldn't have been able to close the deal." (Owner - Component Supplier 8)

The above statement adds additional insight to our current understanding about the global sources of knowledge, as researchers have increasingly been focusing on the impact of IJVs within their boundaries. This excerpt shows that most of the knowledge related to auto parts manufacturing resides across transnational suppliers' networks, and the suppliers from developing economies cannot leverage this knowledge without the help of organizational-level boundary spanners, namely IJVs established in the developing economies.

Our interviews with the suppliers' managers also indicated that the boundary-spanning role of the assemblers has been helpful for the Pakistani suppliers in reducing the search and coordination costs involved in obtaining knowledge from outside sources. This finding supports the earlier work of organization theorists that found boundary-spanning individuals to be cost effective compared with other communication channels across organizational boundaries (Arrow, 1974; March and Simon, 1958; Tushman and Scanlan, 1981).

The suppliers also suggested that the IJVs had played a role in motivating both the global tier1 suppliers and the Pakistani suppliers to form collaborations that support the transfer of knowledge so that they can source particular parts in the host market and reduce the uncertainty of long supply chains. The boundary-spanning role of IJVs has also helped in promoting crosscultural socio-technical ties among the global tier 1 and local Pakistani suppliers. The local suppliers' managers suggested that they had been visiting the Japanese suppliers' plants on the basis of dialogues between the two, initiated by the IJVs. As one managing director of a supplier stated:

\begin{abstract}
"It was through these visits to the Japanese suppliers' plants initiated by our client [an assembler] that we were able to learn various practices from these suppliers and we implemented these into our operations. These visits also resulted in broad social and technical bonds and communications with the Japanese suppliers and resulted in the improvement of our design and components manufacturing capabilities through collaboration with the Japanese suppliers." [Managing Director - Supplier Firm 29]
\end{abstract}

Our interviews with the assemblers also demonstrated the help they had provided to the local component suppliers in linking them up with their first-tier suppliers based in Japan. The 
assemblers' managers frequently mentioned their ability to successfully broker collaboration deals between the local Pakistani and global tier 1 suppliers as, without their intervention, the global tier 1 suppliers did not want to pass on knowledge to the Pakistani suppliers. One of the interviewees said:

"Using our relationship leverage we acted as a facilitator in linking up our local Pakistani suppliers with our first-tier suppliers in Japan.... As you can see, without our assistance, those first-tier suppliers based in Japan would have been reluctant to transfer technological knowledge to Pakistani suppliers." [Deputy Manager for Supplier's Development - Assembler 01]

It was also evident from the interview data that the assemblers had coordinated and negotiated global knowledge transfer to local Pakistani suppliers and protected the leakage of this knowledge in the host economy. Through their role as boundary spanners, the assemblers created trust and confidence on the part of the global suppliers that the local suppliers would use that knowledge only for the part they were to manufacture for their assemblers. In addition, by performing their role as boundary spanners, the assemblers were trying to meet the host government's requirement that they source parts locally and develop the local Pakistani suppliers' capabilities.

Our interviews with government officials from the MOI\&P suggested that the government had also played a key role in encouraging the three assemblers to help the local Pakistani suppliers to develop by linking them with their global supply base. The Deputy Secretary of MOI\&P told us,

"The OEMs based in the auto sector of Pakistan have helped many of our local suppliers in negotiating technology transfer from their global suppliers, because without the help of these three IJVs (assemblers), global first-tier suppliers are reluctant to 'join hands' with the Pakistani suppliers. So we have to keep our policies 
friendly for these assemblers as long as they help with the development of local suppliers' capabilities." [Deputy Secretary, MOI\&P]

\section{Social capital and the boundary spanner role of the IJVs}

The results indicate that socialization and relational mechanisms were deployed when

engineering staff from the global tier 1 suppliers/IJVs based in Pakistan and local suppliers' staff were involved in moving knowledge from the former suppliers to the latter. As one of the assemblers noted,

"Our firm has played an important role as a facilitator and mediator of technology transfer to Pakistan-based suppliers. As you can see, we have a good business relationship based on mutual trust and durable relationships with our tier 1 suppliers in Japan and elsewhere in the world." [Deputy Manager of Supplier's Development - Assembler 02]

Also, the Deputy Manager for the Supply Chain of one of the suppliers indicated the criticality of social capital in the process of knowledge transfer between his firm and the global tier 1 suppliers:

“... For successful knowledge transfer, you need to have long-term associations with the transferor of the knowledge, and in order for the critical knowledge transfer to take place, both sides need to have staff socialization activities and staff visits at which issues related to the absorption of the knowledge are hammered out. In our case, we have visited Japanese suppliers' plants, and their staff have been visiting our facilities on a continuous basis, to help us make this a smooth transfer." [Deputy Manager of Supply Chain - Component Supplier 25].

Table 5 below shows the component suppliers' technical collaborations in relation to different components, achieved with the help of the three automotive assemblers. Given the disruptive structure of Pakistan's automotive industry from the local tier 1 suppliers' perspective 
(see Figure 1), IJVs link the latter with the IJVs' parents' global value chain networks, such as global tier 1 component suppliers located in Japan and South Korea (see Table 5).

Insert Table 5 about here

Our findings suggest that social capital developed between the local Pakistani suppliers, the IJVs and their transnational tier 1 suppliers has been important in enhancing the role the IJVs have played as boundary spanners. Our interviews with the suppliers' managers have shown that personalized ties to the three assemblers have been helpful in allowing them to form successful collaborations and receive valuable knowledge from the global tier 1 suppliers. On the basis of the local suppliers' social ties with the three assemblers, the latter have played an important role in linking them to their global tier 1 suppliers. An important insight from the data is that the IJVs have built trust between the global tier 1 suppliers and the Pakistani suppliers. This has facilitated the international knowledge transfer to Pakistani suppliers. IJVs' role as boundary spanners has been important in the development of relationships between global and local suppliers and knowledge transfer to the local Pakistani suppliers. One of the interviewees explained:

"The assemblers have trustworthy relationships with their global suppliers and they have been working with them for a long time, so this relationship leverage has been helpful [for us] in getting the key technological knowledge from tier 1 suppliers in Japan, and we have successfully collaborated through the help of the assembler." [Deputy Managing Director - Component Supplier 2]

However, we also came across some suppliers who had not developed strong social ties with the assemblers, and were in a weak position in terms of forming any collaborations with the global tier 1 suppliers through the help of the assemblers. One interviewee commented: 
"We don't have good connections with our assemblers, as our relationship is mainly market based. We hardly interact with the assemblers' key staff and the assemblers have not helped us in hooking up with their global suppliers. The global suppliers have a wealth of knowledge about components manufacturing and they control the key component drawings, and if we had good social ties with the assemblers like some of the other suppliers, we would also have benefited like they have." [Owner Component Supplier 23].

These comments highlight the importance of local social capital in enhancing the boundary-spanning role of IJVs. The suppliers that have established social ties with the assemblers are in a better position to get connected with the global tier 1 suppliers through the assembler-initiated boundary-spanning activities, and thus to receive knowledge from the global suppliers. On the other hand, the suppliers that lack social capital with the assemblers are in a weak position and unlikely to receive international knowledge through this channel.

\section{DISCUSSION}

\section{Role of IJVs as boundary spanners}

Research in the area of knowledge transfer has been focused within the boundaries of the firm. Much of the knowledge, however, resides across global networks, and it is therefore difficult for local firms to access knowledge and develop their capabilities. We investigate the boundaryspanning role of the IJVs, in particular, in the transfer of international knowledge to local firms, and in linking local firms with the global sources of knowledge. Much of the research around the boundary-spanning role has focused on individuals acting as boundary spanners in linking their organization with its external environment (e.g. Aldrich and Herker, 1977; Allen and Cohen, 1969; Tushman and Scanlan, 1981). Based on our empirical study of IJVs acting as boundary spanners in the transfer of international knowledge, we have found that boundary spanning is associated with the organizational level as well as the individual one. Our results indicate that 
IJVs play an important role as boundary spanners in the transfer of international knowledge, and facilitate the development of cross-cultural socio-technical ties amongst emerging economies' suppliers and global tier 1 suppliers.

Our findings indicate that IJVs formed in an emerging economy can act as boundary spanners by connecting their host country's suppliers with their parent's global networks (see Table 5). Under this boundary-spanner structure (i.e. MNEs' global knowledge networks-IJVs invested in by these MNEs-IJVs' local suppliers), the IJVs facilitate technological knowledge transfer, and furthermore coordinate and configure business activities amongst the network suppliers. The IJVs in the host economy also allow previously unconnected suppliers to connect with the global networks, enabling technological knowledge transfer. This highlights the complementary roles of these boundary spanners, in both knowledge transfer and capability building in emerging economies. As such, our findings provide important clues about the vital role IJVs play in the host economies by negotiating and initiating dialogues for technological knowledge transfer between the local supplier networks and global networks when critical knowledge resides in the latter.

\section{The role of social capital in knowledge transfer within the network}

The findings suggest that, in technological knowledge transfer, the nature of the relationships between the parties is important. The technology provider's willingness and motivation to help the local suppliers is key to the successful transfer of the technology, and to the establishment of links with the global production networks. Personalized ties and ongoing discussions with the providers of knowledge are important for local component suppliers as they help to initiate the dialogues with global first-tier suppliers, and most of the knowledge resides across value networks. The results indicate that local social capital harnesses the boundary-spanning role of 
the IJVs in developing and emerging economies, whereas a lack of local social capital hinders it. Overall, our findings point out that long-term relationships based on mutual trust, and the willingness of the senders (assemblers) of technology to help the local suppliers to link up with their global first-tier suppliers, are critical factors for the linking up of these lower-tier suppliers with the global production networks. Figure 2 illustrates the associations identified among the MNEs' global networks, the boundary spanner role of IJVs in technological knowledge transfer, and knowledge transfer at the local tier 1 supplier level. As shown in Figure 2, IJVs' boundary spanning is conceptualized as encompassing and connecting the MNEs global knowledge network- knowledge reservoir to the previously unconnected emerging economies' firms. These local firms in the emerging economies operate at the lower tiers of the value chain as shown in Figure 1. Our framework indicates the importance global knowledge transfer through boundary spanners and the moderating role of social capital, which are discussed in the extant literature as isolated issues with no apparent connections. In our extended framework, it identifies four factors (i.e., MNEs' global knowledge networks, IJVs as boundary spanners, social capital between IJVs and local firms, and technological knowledge transfer) which are dynamically interlinked, and demonstrates the boundary spanning roles of the IJVs as covering the extent of the dynamics of global-local knowledge connections.

Insert Figure 2 about here 


\section{Theoretical contributions}

This study represents a first step toward building an understanding of the organizational-level boundary-spanning role IJVs play in the transfer of international knowledge to local suppliers based in emerging economies. It makes four key contributions to the literature on knowledge transfer in general and knowledge transfer through IJVs down the local supply chain in particular. Firstly, it provides detailed firm-level empirical evidence of the role of boundary spanners (i.e. IJVs) when knowledge has to move from outside their own boundaries (EasterbySmith et al., 2008). The findings of this research also indicate that IJVs have acted as facilitators of technological knowledge transfer for the Pakistani component suppliers by linking them with their tier 1 suppliers in Japan and elsewhere in the world. This result is in contrast to the findings of the previous literature, which has not properly captured MNEs' facilitative role, and particularly that of IJVs, in the transfer of technological knowledge (e.g. Duanmu and Fai, 2007; Dyer and Hatch, 2006; Ivarsson and Alvstam, 2005; Zhao et al., 2005). The current paper links IJVs' domestic component suppliers with their established networks of global tier 1 suppliers based in developed countries, the latter being a key source of technology transfer. Thus, the facilitative role of IJVs is critical for initiating the knowledge transfer process between network members when the knowledge resides with other members of the network and not the IJVs themselves. In line with this, we acknowledge the importance of the role IJVs play, in that it is not limited to the IJVs' partners but can be extended beyond their boundaries, something that has been neglected by the extant research (Child and Yan, 2001; Lane et al., 2001). Thus, our study presents novel empirical insights into the boundary spanning roles of the IJVs. This work extends previous conceptualizations of the individual boundary spanner role to the context of 
IJVs acting as organizational-level boundary spanners in order to transfer international knowledge to local suppliers.

Secondly, the previous work on the competitiveness of MNEs has acknowledged the important role of dispersed global knowledge, as one of the key ingredients of MNEs' competitiveness (Gupta and Govindarajan, 1991; Kogut and Zander, 1992). So far, this work has focused on knowledge flow and the recombination of this knowledge within the context of the MNEs themselves. Our study extends this work to the context of the IJVs, and to their locally owned suppliers' networks. It provides important insights into the role of the IJVs as boundary spanner for the transfer of globally dispersed network knowledge to unconnected network members, i.e., local suppliers in developing economies. Thus, the boundary-spanning role of IJVs reduces the search costs involved in knowledge identification and development for the previously less connected emerging economy suppliers. Also, our study contributes to the strategic management literature by identifying the strategic boundary-spanning role of the IJVs in developing combinative capabilities in their local host country suppliers (Kogut and Zander, 1992; Teece et al., 1997). The roles the IJVs play in emerging economies are much broader than previously discussed, including the enhancement of the entire local capability development process through boundary-spanning activities, and not just the development and maintenance of network relationships (Kale, Dyer, and Singh, 2002; Simonin, 1997). Hence, the boundaryspanning activities of these IJVs in emerging economies can help to tackle the issue of knowledge asymmetry amongst the global and local network suppliers.

Our findings indicate that local suppliers in the lower-tier segments can also successfully utilize the social ties and trust of their component buyers so as to acquire complex parts technology in return for upgrading their engineering and design capabilities (see Table 5). In the 
past, IB researchers have focused their attention on the IJV partner context. The current paper explains the role of IJVs as facilitators of technological knowledge transfer when suppliers in emerging countries have low connectivity within the IJVs' global supplier networks, and are stuck in the lower tiers of the supply chain. Thus, it makes an important contribution to the literature on the KBV and MNEs' FDI in the emerging economy context.

Next, the traditional literature on social capital ignores the formal role of boundary spanners in the interorganizational context. Also, a majority of studies on formal interorganizational knowledge governance have focused on knowledge protection/deterrence mechanisms (e.g. process/output controls based on legal contracts), theoretically based on transaction cost economics. In this paper, we argue that boundary spanners can be important in the moving of diverse knowledge from distant networks by facilitating a shared vision and curbing opportunism amongst network partners (Tsai, 2001). Unlike previous research highlighting MNE-subsidiary and parent-IJV contexts, we argue that the boundary-spanning role of IJVs in emerging economies should be viewed from the perspective of the wider context in which these IJVs operate their value chain activities. Thus, our findings extend the discussions of knowledge governance at the interorganizational level to the network level in the context of knowledge transfer between MNEs, IJVs, and local suppliers.

Lastly, our findings specifically show that the willingness of the parties involved in the transfer of technological knowledge serves as an important condition for its successful transfer in emerging economies. Thus, these findings complement existing studies, mainly in the context of MNEs, which indicate that the motivation to transfer knowledge is positively related to the outcome of knowledge transfer (Gupta and Govindarajan, 2000; Minbaeva and Michailova, 2004; Minbaeva, Pedersen, Björkman, Fey, and Park, 2003). 
Overall, the findings of this study represent an important advancement in our understanding of how knowledge is transferred and acquired in the interorganizational context, and especially by emerging economies' component suppliers. Combining both formal (i.e., boundary spanners) and informal (i.e., personalized ties and trust) elements, this study suggests an integrative way of studying the role of social capital and knowledge flow that contributes to the ongoing debates on knowledge transfer and organizational learning (Argote, McEvily, and Reagans, 2003).

\section{Revising the theory of boundary spanners}

In this paper, we consider the 'boundary spanner' theory to be a useful theoretical lens through which to study the organizational-level role of boundary spanners in the transfer of global knowledge to emerging economy firms. This adds unique insights to the field of IB, as we lack sufficient understanding about the organizational-level role of boundary spanning. However, the extant research around boundary spanners has focused on the role of individual boundary spanners within organizations. The current theory on this individual role underestimates the importance of cross-border knowledge asymmetry between emerging economy firms and their developed economy counterparts. We have also observed a number of modest departures from the current predictions of this theory. With regard to boundary-spanning activities, we note that the local social capital plays an important role in harnessing the potential of organizational-level boundary spanners, in our case the IJVs and the local firms. Another important insight that is lacking in the current theory of boundary spanners is that boundary-spanner-induced differentiation and the recipients of knowledge diversity are the key determinants of the effective functioning of the boundary spanners' role. 


\section{Managerial and practical implications}

This research provides important managerial and practical implications by highlighting that MNEs', and especially IJVs', social capital should be widely utilized to gain access to the global network's stock of technological knowledge. This finding underscores the necessity for managers and practitioners to develop and promote strong personal connections with the providers of technology by attending social/cultural functions/trips. Interorganizational communication mechanisms should also be enhanced and developed so as to build personal connections and receive technological know-how through network partners.

\section{Limitations and research directions}

We should mention some of the limitations of this study, which point to directions for future research. First, although the collection of data through the use of interviews from three automotive assemblers, 50 of their tier 1 suppliers and the MOI\&P in Pakistan provided valuable insights, the possibility of cognitive bias from some of the respondents cannot be entirely ruled out. However, the inclusion of the first and last of these three sources reduced our concerns in this regard. The IJVs in the emerging economies may also perform different boundary spanning roles, i.e., bridging and bonding boundary spanners. Future research may need to investigate the joint effect of bridging and bonding roles of the boundary spanners in the transfer of knowledge. Also future research may need to extend these findings to other industries or to a cross-country context within the automotive industry as this would provide more useful insights for corroboration purposes. The roles of IJVs as boundary spanners of technology transfer need to be formally recognized and empirically tested in future research. In this regard, longitudinal studies of IJVs boundary spanning roles could be conducted to test and further refine the boundary spanner framework in Figure 2 to gain additional insights. Lastly, this study did not investigate 
management control and decision making within equity IJVs. We cautiously speculate that the governance structures of IJVs might produce different types of boundary spanners and correspondingly different effects on knowledge transfer from global to local network suppliers. Related to this, we suggest that future research investigates the conditions under which the boundary-spanning activity of the IJVs is efficient and effective.

\section{CONCLUSION}

In sum, this study highlights the important role IJVs play as boundary spanners in the context of emerging economies. We have argued that the mere establishment of IJVs does not automatically mean that technological knowledge will be transferred to the wider host networks. Instead, we have demonstrated how IJVs act as boundary spanners between their parents' networks and the host country's less connected networks. At the same time, we have explained how and why technological knowledge is transferred between networks in two different contexts. IJVs play their role as boundary spanners in the transfer of knowledge from the developed country's network to the developing country's network in order to give the latter country's suppliers the opportunity to use this knowledge to develop their technological capabilities (e.g. engineering and design capabilities). This will in turn help the local IJVs in their supply chain dealings with the local (emerging country's) suppliers, thus benefiting both parties.

\section{Acknowledgements}

The authors gratefully acknowledge stimulating discussions arising within the Manchester Business School CIBER seminars (http://www.mbs.ac.uk/ciber). Specifically, the constructive feedback of Mo Yamin and Noemi Sinkovics and the extraordinary editorial support of Stephen Tallman and two anonymous reviewers was instrumental in developing this paper. 


\section{REFERENCES}

Ahuja G. 2000. Collaboration networks, structural holes and innovation: A longitudinal study. Administrative Science Quarterly 45(3): 425-455.

Aldrich H, Herker D. 1977. Boundary spanning roles and organization structure. Academy of Management Review 2(2): 217-230.

Allen TJ. 1977. Managing the flow of technology. MIT Press: Cambridge, MA.

Allen TJ, Cohen SI. 1969. Information flow in research and development laboratories. Administrative Science Quarterly 14(1): 12-19.

Ancona DG, Caldwell DF. 1992. Bridging the boundary: External activity and performance in organizational teams. Administrative Science Quarterly 37(4): 634-665.

Argote L, McEvily B, Reagans R. 2003. Managing knowledge in organizations: An integrative framework and review of emerging themes. Management Science 49(4): 571-582.

Arrow KE. 1974. The limits of organization. W.W. Norton \& Company: New York.

Barney JB. 1986. Strategic factor markets: Expectations, luck, and business strategy. Management Science 32(10): 1231-1241.

Beamish PW. 1993. The characteristics of joint ventures in the Peoples' Republic of China. Journal of International Marketing 1(2): 29-48.

Bechky BA. 2003. Sharing meaning across occupational communities: The transformation of knowledge on a production floor. Organization Science 14(3): 312-330.

Bell MP, Harrison DA. 1996. Using intra-national diversity for international assignments: A model of bicultural competence and expatriate adjustment. Human Resource Management Review 6(1): 47-74.

Bhagat R, Harveston PD, Triandis HC. 2002. Cultural variations in the cross-border transfer of organizational knowledge: An integrative framework. Academy of Management Review 27(2): 204-221.

Birkinshaw J, Brannen MY, Tung RL. 2011. From a distance and generalizable to up close and grounded: Reclaiming a place for qualitative methods in international business research. Journal of International Business Studies 42(5): 573-581.

Blalock G. 2001. Technology from foreign direct investment: Strategic transfer through supply chains. Mimeo: University of California, Berkeley.

Blau PM. 1964. Exchange and power in social life. Wiley: New York.

Boersma MF, Buckley PJ, Ghauri PN. 2003. Trust in International Joint Venture Relationships. Journal of Business Research 56(12): 1031-1042.

Brannen MY, Thomas DC. 2010. Bicultural Individuals in Organizations Implications and Opportunity. International Journal of Cross Cultural Management 10(1): 5-16.

Breznitz D, Murphree M. 2011. Run of the Red Queen: Government, Innovation, Globalization, and Economic Growth in China. Yale University Press.

Carlile PR. 2002. A pragmatic view of knowledge and boundaries: Boundary objects in new product development. Organization science 13(4): 442-455.

Child J, Yan Y. 2001. National and transnational effects in international business: indications from Sino-foreign joint ventures. Management International Review 41(1): 53-70. 
Cohen WM, Levinthal DA. 1990. Absorptive capacity: a new perspective on learning and innovation. Administrative Science Quarterly 35(1): 128-152.

Cook SDN, Brown JS. 1999. Bridging Epistemologies: The Generative Dance between Organizational Knowledge and Organizational Knowing. Organization Science 10(4): $381-400$.

Cross R, Nohria N, Parker A. 2002. Six myths about informal networks--and how to overcome them. MIT Sloan Management Review 43(3): 67-75.

Cross R, Parker A. 2004. The hidden power of social networks: Understanding how work really gets done in organizations. Harvard Business Press.

Cullen JB, Johnson JL, Sakano T. 2000. Success through Commitment and Trust: The Soft Side of Strategic Alliance Management. Journal of World Business 35(3).

Davenport TH, Prusak L. 1998. Working knowledge: Managing what your organization knows. Harvard Business School Press, Boston, MA.

Dhanaraj C, Lyles MA, Steensma HK, Tihanyi L. 2004. Managing tacit and explicit knowledge transfer in IJVs: the role of relational embeddedness and the impact on performance. Journal of International Business Studies 35(5): 428-442.

Doz Y. 2011. Qualitative research for international business. Journal of International Business Studies 42(5): 582-590.

Duanmu J, Fai F. 2007. A processual analysis of knowledge transfer: From foreign MNEs to Chinese suppliers. International Business Review 16(4): 449-473.

Dyer J, Hatch NW. 2006. Relation-specific capabilities and barriers to knowledge transfers: creating competitive advantage through network relationships. Strategic Management Journal 27(8): 701-719.

Dyer J, Nobeoka K. 2000. Creating and managing a high performance knowledge-sharing network: the Toyota case. Strategic Management Journal 21(3): 345-367.

Dyer J, Singh H. 1998. The relational view: Cooperative strategy and sources of interorganizational competitive advantage. Academy of Management Review 23(4): 660679.

Easterby-Smith M, Lyles MA, Tsang EWK. 2008. Inter Organizational Knowledge Transfer: Current Themes and Future Prospects. Journal of Management Studies 45(4): 667-690.

Faems D, Janssens M, Madhok AM, van Looy B. 2008. Toward an Integrative Respective on Alliance Governance: Connecting Contract Design, Trust Dynamics, and Contract Application. Academy of Management Journal 51(6): 1053-1078.

Fleming L, Waguespack DM. 2007. Brokerage, boundary spanning, and leadership in open innovation communities. Organization Science 18(2): 165-184.

Friedman RA, Podolny J. 1992. Differentiation of Boundary Spanning Roles: Labor Negotiations and Implications for Role Conflict. Administrative Science Quarterly 37(1): 28-47.

Gereffi G, Humphrey J, Sturgeon T. 2005. The governance of global value chains. Review of international political economy 12(1): 78-104.

Giuliani E, Pietrobelli C, Rabellotti R. 2005. Upgrading in global value chains: lessons from Latin American clusters. World development 33(4): 549-573.

Gould RV, Fernandez RM. 1989. Structures of mediation: A formal approach to brokerage in transaction networks. Sociological methodology 19: 89-126.

Granovetter M. 1992. Problems of explanation in economic sociology. In Networks and organizations: structure, form, and action. Nohria N, Eccles R (eds.), Harvard Business School Press: Boston, MA. 
Grant RM. 1996. Toward a knowledge-based theory of the firm. Strategic Management Journal 17(10): 109-122.

Gulati R. 1999. Network location and learning: the influence of network resources and firm capabilities on alliance formation. Strategic Management Journal 20(5): 397-420.

Gulati R, Nickerson JA. 2008. Interorganizational trust, governance choice, and exchange performance. Organization Science 19(5): 688-708.

Gupta A, Govindarajan V. 1991. Knowledge flows and the structure of control within multinational corporations. Academy of Management Review 16(4): 768-792.

Gupta A, Govindarajan V. 2000. Knowledge flows within multinational corporations. Strategic Management Journal 21(4): 473-496.

Hansen M. 1999. The search-transfer problem: The role of weak ties in sharing knowledge across organization subunits. Administrative Science Quarterly 44: 82-111.

Hansen MT. 2002. Knowledge networks: Explaining effective knowledge sharing in multiunit companies. Organization Science 13(3): 232-248.

Hargadon A, Sutton RI. 1997. Technology brokering and innovation in a product development firm. Administrative Science Quarterly 42(4): 716-749.

Henderson RM, Clark KB. 1990. Architectural innovation: The reconfiguration of existing product technologies and the failure of established firms. Administrative Science Quarterly 35(1): 9-30.

Humphrey J, Memedovic O. 2003. The global automotive industry value chain: What prospects for upgrading by developing countries. UNIDO Sectorial Studies Series Working Paper.

Hymer SH. 1960. The international operations of national firms: A study of direct foreign investment. MIT Press: Cambridge, Mass.

Inkpen AC. 2000. Learning through Joint Ventures: A framework of knowledge acquisition. Journal of Management Studies 37(7): 1019-1043.

Inkpen AC, Tsang EWK. 2005. Networks, social capital, and learning. Academy of Management Review 30(1): 146-165.

Ivarsson I, Alvstam CG. 2005. Technology transfer from TNCs to local suppliers in developing countries: A study of AB Volvo's truck and bus plants in Brazil, China, India, and Mexico. World Development 33(8): 1325-1344.

Javorcik BS. 2004. Does foreign direct investment increase the productivity of domestic firms? In search of spillovers through backward linkages. The American Economic Review 94(3): 605-627.

Johnson KL, Duxbury L. 2010. The view from the field: A case study of the expatriate boundary-spanning role. Journal of World Business 45(1): 29-40.

Kale P, Dyer J, Singh H. 2002. Alliance capability, stock market response, and long term alliance success: The role of the alliance function. Strategic Management Journal 23(8): 747-767.

Kale P, Singh H, Perlumutter H. 2000. Learning and Protection of Proprietary Assets in Strategic Alliances: Building Relational Capital. Strategic Management Journal 21(3): 217-237.

Kast FE, Rosenzweig JE. 1970. Organization and management theory: A systems approach. $N Y$ : McGraw-Hill.

Kim L. 1997. Imitation to Innovation: The Dynamics of Korea's Technological Learning. Harvard Business School Press: Boston.

Kim T-Y, Oh H, Swaminathan A. 2006. Framing interorganizational network change: a network inertia perspective. Academy of Management Review 31(3): 704-720. 
Kogut B, Zander U. 1992. Knowledge of the firm, combinative capabilities, and the replication of technology. Organization Science 3(3): 383-397.

Kolbe RH, Burnett MS. 1991. Content-Analysis Research: An Examination of Applications with Directives for Improving Research Reliability and Objectivity. Journal of Consumer Research 18(2): 243-250.

Kostova T, Roth K. 2003. Social capital in multinational corporations and a micro-macro model of its formation. Academy of Management Review 28(2): 297-317.

Lane PJ, Salk JE, Lyles MA. 2001. Absorptive capacity, learning, and performance in international joint ventures. Strategic Management Journal 22(12): 1139-1161.

Leifer R, Delbecq A. 1978. Organizational/environmental interchange: a model of boundary spanning activity. Academy of Management Review 3(1): 40-50.

Levina N, Vaast E. 2005. The emergence of boundary spanning competence in practice: implications for implementation and use of information systems. MIS Quarterly 29(2): 335-363.

Liebeskind JP. 1996. Knowledge, strategy and the theory of the firm. Strategic Management Journal 17(SI): 93-107.

Liu C-L, Ghauri PN, Sinkovics RR. 2010. Understanding the Impact of Relational Capital and Organizational Learning on Alliance Outcomes. Journal of World Business 45(3): 237249.

Lyles MA, Salk JE. 1996. Knowledge acquisition from foreign parents in international joint ventures: an empirical examination in the Hungarian context. Journal of International Business Studies 27(5): 877-903.

Madhok A. 1995. Opportunism and Trust in Joint Venture Relationships: An Exploratory Study and Model. Scandinavian Journal of Management 11(1): 57-74.

Malik T. 2012. Disparate association between alliance social capital and the global pharmaceutical firms' performance. International Business Review 21(6): 1017-1028.

March JG, Simon HA. 1958. Organizations. Wiley: New York.

Marrone JA, Tesluk PE, Carson JB. 2007. A Multilevel Investigation of Antecedents and Consequences of Team Member Boundary-Spanning Behavior. Academy of Management Journal 50(6): 1423-1439.

Marschan-Piekkari R, Welch C. 2004. Handbook of qualitative research methods for international business. Edward Elgar Publishing.

Marsden PV. 1990. Network data and measurement. Annual Review of Sociology 16: 435-463.

Meyer KE. 2004. Perspectives on multinational enterprises in emerging economies. Journal of International Business Studies 35(4): 259-277.

Meyer KE, Sinani E. 2009. When and where does foreign direct investment generate positive spillovers? A meta- analysis. Journal of International Business Studies 40(7): 1075-1094.

Miles M, Huberman AM. 1994. Qualitative data analysis - An expanded sourcebook. Sage: Newbury Park, CA.

Miller JG. 1972. Living systems: The organization. Behavioral Science 17(1): 1-182.

Minbaeva DB, Michailova S. 2004. Knowledge transfer and expatriation in multinational corporations: The role of disseminative capacity. Employee Relations 26(6): 663-679.

Minbaeva DB, Pedersen T, Björkman I, Fey CF, Park HJ. 2003. MNC knowledge transfer, subsidiary absorptive capacity, and HRM. Journal of International Business Studies 34(6): 586-599. 
Moran TH. 2005. How does FDI affect host country development? Using industry case studies to make reliable generalizations. In Does foreign direct investment promote development? Moran TH, Graham EM, Blomström M (eds.), Institute for International Economics: Dulles

Mors ML. 2010. Innovation in a global consulting firm: When the problem is too much diversity. Strategic Management Journal 31(8): 841-872.

Mudambi R, Swift T. 2009. Professional guilds, tension and knowledge management. Research Policy 38(5): 736-745.

Nahapiet J, Ghoshal S. 1988. Social capital, intellectual capital, and the organizational advantage. Academy of Management Review 23: 242-266.

Nelson R, Winter S. 1982. An evolutionary theory of economic change. Harvard University Press: Cambridge, MA.

Nonaka I, Takeuchi H. 1995. The knowledge- creating company. Oxford University Press: New York.

Nonaka I, Toyama R, Konno N. 2000. SECI, Ba and leadership: A unified model of dynamic knowledge creation. Long Range Planning 33(1): 5-34.

Park BI. 2011. Knowledge transfer capacity of multinational enterprises and technology acquisition of in international joint ventures. International Business Review 20(1): 75-87.

Patriotta G, Castellano A, Wright M. 2013. Coordinating knowledge transfer: Global managers as higher-level intermediaries. Journal of World Business 48(4): 515-526.

Pawlowski SD, Robey D. 2004. Bridging user organizations: Knowledge brokering and the work of information technology professionals. MIS quarterly 28(4): 645-672.

Pérez-Nordtvedt L, Kedia BL, Datta DK, Rasheed AA. 2008. Effectiveness and efficiency of cross-border knowledge transfer: an empirical examination. Journal of Management Studies 45(4): 714-744.

Phelps C, Heidl R, Wadhwa A. 2012. Knowledge, networks, and knowledge networks: a review and research agenda. Journal of Management 38(4): 1115-1166.

Polanyi M. 1962. Personal knowledge: towards a post critical philosophy. University of Chicago Press: IL.

Quadros R. 2004. Global quality standards and technological upgrading in the Brazilian autocomponents industry. In Local enterprises in the global economy: Issues of governance and upgrading. Schmitz H (ed.), Edward Elgar: Northampton.

Reagans R, McEvily B. 2003. Network structure and knowledge transfer: the effects of cohesion and range. Administrative Science Quarterly 48(2): 240-267.

Reiche BS. 2011. Knowledge transfer in multinationals: The role of inpatriates' boundary spanning. Human Resource Management 50(3): 365-389.

Reiche BS, Harzing A-W, Kraimer ML. 2008. The role of international assignees' social capital in creating inter-unit intellectual capital: A cross-level model. Journal of International Business Studies 40(3): 509-526.

Ring PS, van de Ven AH. 1994. Developmental processes of cooperative interorganizational relationships. Academy of Management Review 19(1): 90-118.

Rosenkopf L, Nerkar A. 2001. Beyond local search: boundary-spanning, exploration, and impact in the optical disk industry. Strategic Management Journal 22(4): 287-306.

Simonin BL. 1997. The importance of collaborative know how: An empirical test of the learning organisation. Academy of Management Journal 40(5): 1150-1174. 
Simonin BL. 1999. Ambiguity and the process of knowledge transfer in strategic alliances. Strategic Management Journal 20(7): 535-623.

Sinkovics RR, Penz E, Ghauri PN. 2008. Enhancing the trustworthiness of qualitative research in international business. Management International Review 48(6): 689-714.

Starbuck WH. 1976. Organizations and their Environments. In Handbook of Industrial and Organizational Psychology. Dunnette MD (ed.), Rand McNally: New York.

Sturgeon T, Florida R. 2005. Globalization, Deverticalization, and Employment in the Motor Vehicle Industry. In Locating Global Advantage, Industry Dynamics in the International Economy. Kenney M, Florida R (eds.), Stanford University Press: Palo Alto.

Sturgeon T, Van Biesebroeck J, Gereffi G. 2008. Value chains, networks and clusters: reframing the global automotive industry. Journal of Economic Geography 8(3): 297-321.

Swan J, Scarbrough H. 2001. Knowledge management: Concepts and controversies. Journal of Management Studies 38(7): 913-921.

Szulanski G. 1996. Exploring internal stickiness: impediments to the transfer of best practice within the firm. Strategic Management Journal 7(SI Winter): 27-43.

Szulanski G, Cappetta R, Jensen RJ. 2004. When and how trustworthiness matters: knowledge transfer and the moderating effect of casual ambiguity. Organization Science 15(5): 600613.

Teece DJ, Pisano G, Shuen A. 1997. Dynamic capabilities and strategic management. Strategic Management Journal 18(7): 509-533.

Tortoriello M, Krackhardt D. 2010. Activating cross-boundary knowledge: The role of Simmelian ties in the generation of Innovations. Academy of Management Journal 53(1): 167-181.

Tsai W. 2001. Knowledge transfer in intraorganizational networks: Effects of network position and absorptive capacity on business unit innovation and performance. Academy of Management Journal 44(5): 996-1004.

Tsai W, Ghoshal S. 1998. Social capital and value creation: the role of intrafirm networks. Academy of Management Journal 41(4): 464-476.

Tsang EW, Nguyen DT, Erramilli MK. 2004. Knowledge Acquisition and Performance of International Joint Ventures in the Transition Economy of Vietnam. Journal of International Marketing 12(2): 82-103.

Tushman ML. 1977. Special boundary roles in the innovation process. Administrative Science Quarterly 22(4): 587-605.

Tushman ML, Katz R. 1980. External communication and project performance: an investigation into the role of gatekeepers. Management Science 26(11): 1071-1085.

Tushman ML, Scanlan TJ. 1981. Boundary spanning individuals: Their role in information transfer and their antecedents. Academy of Management Journal 24(2): 289-305.

Utterback JM. 1971. The process of technological innovation within the firm. Academy of Management Journal 14(1): 75-88.

Uzzi B. 1997. Social structure and competition in interfirm networks: the paradox of embeddedness. Administrative Science Quarterly 42(1): 35-67.

von Hippel E. 1988. The sources of innovation. Oxford University Press: New York.

World Bank. 1993. Foreign direct investment: benefits beyond insurance, Development Economics Vice-Presidency: Washington, D.C.

World Bank. 2010. Ease of doing business index. http://www.doingbusiness.org/rankings (12 December 2010). 
Zahra SA, Ireland RD, Hitt MA. 2000. International expansion by new venture firms: International diversity, mode of market entry, technological learning, and firm performance. Academy of Management Journal 43(5): 925-950.

Zander U, Kogut B. 1995. Knowledge and the speed of the transfer and imitation of organizational capabilities: An empirical test. Organization Science 6(1): 76-92.

Zhao Z, Anand J, Mitchell W. 2005. A dual networks perspective on inter-organizational transfer of R\&D capabilities: international joint ventures in the Chinese automotive industry. Journal of Management Studies 42(1): 127-160.

Zhao ZJ, Anand J. 2013. Beyond boundary spanners: the 'collective bridge' as an efficient interunit structure for transferring collective knowledge. Strategic Management Journal 34(13): 1513-1530. 


\section{TABLES AND FIGURES}

\section{Europe and US}

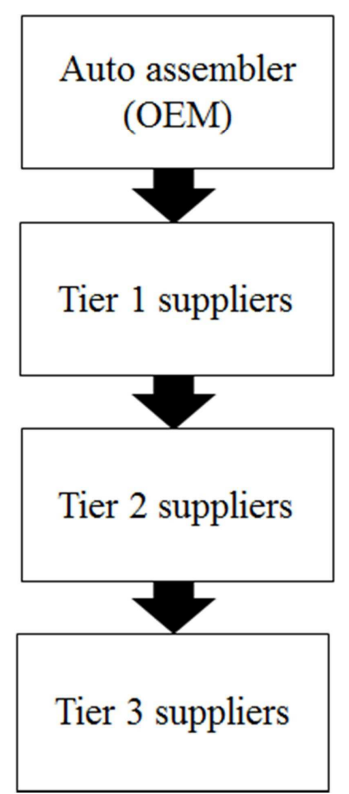

Pakistan

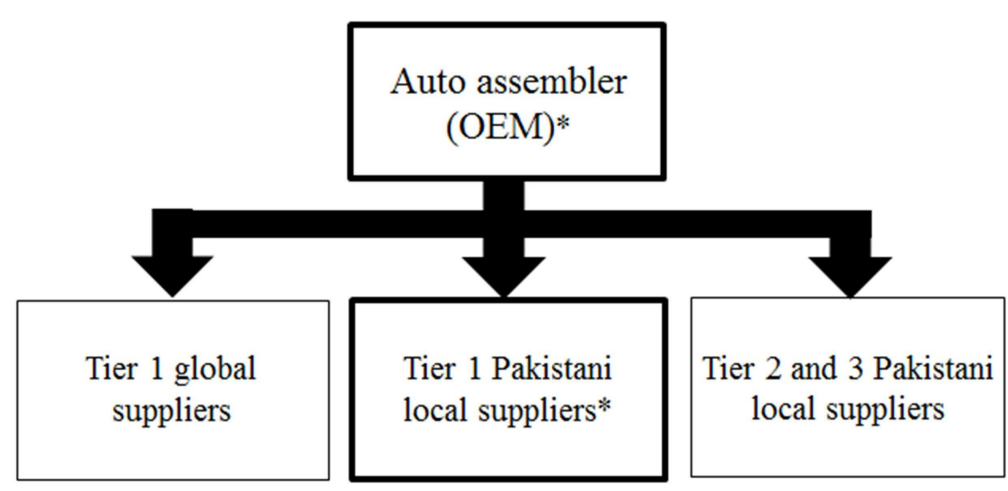

* The auto assemblers are the IJVs that are the focus of this paper

Figure 1: Comparison of automotive industries 
Table 1: The evolution of Pakistan's automotive industry

\begin{tabular}{|c|c|c|c|}
\hline Year & Manufacturing Assembly & Vehicles & Company \\
\hline $\begin{array}{l}\text { 1950s - Private } \\
\text { sector }\end{array}$ & $\begin{array}{l}\text { Semi knocked down } \\
\text { assembly }\end{array}$ & $\begin{array}{l}\text { Bedford } \\
\text { trucks/buses }\end{array}$ & $\begin{array}{l}\text { General Motors } \\
\text { (GM) }\end{array}$ \\
\hline $\begin{array}{l}\text { 1960s - Private } \\
\text { sector }\end{array}$ & $\begin{array}{l}\text { Semi and complete knocked } \\
\text { down assembly - achieved } \\
40 \% \text { local contents in } \\
\text { Bedford trucks and } 20 \% \text { in } \\
\text { cars }\end{array}$ & $\begin{array}{l}\text { Bedford } \\
\text { trucks/buses, } \\
\text { Vauxhall, Ford } \\
\text { Prefect and Cortina }\end{array}$ & $\begin{array}{l}\text { Gandhara } \\
\text { Industries Ltd. } \\
\text { (formerly GM). }\end{array}$ \\
\hline $\begin{array}{l}\text { 1970s - } \\
\text { Nationalization }\end{array}$ & $\begin{array}{l}\text { Indigenization of components } \\
\text { accelerated, achieving } 80 \% \\
\text { local contents in Bedford } \\
\text { trucks and buses }\end{array}$ & $\begin{array}{l}\text { Bedford } \\
\text { trucks/buses and } \\
\text { cars }\end{array}$ & $\begin{array}{l}\text { Pakistan } \\
\text { Automobile } \\
\text { Corporation } \\
\text { (PACO) }\end{array}$ \\
\hline $\begin{array}{l}\text { 1980s onward - } \\
\text { Privatization and } \\
\text { entry of more } \\
\text { foreign } \\
\text { automotive } \\
\text { assemblers }\end{array}$ & $\begin{array}{l}\text { Manufacturing of cars under } \\
\text { industry- and product-specific } \\
\text { local contents requirements }\end{array}$ & $\begin{array}{l}\text { Suzuki cars, } \\
\text { Toyota, Honda, } \\
\text { Hyundai, Santro, } \\
\text { Kia, and Cuore } \\
\text { cars }\end{array}$ & $\begin{array}{l}\text { PACO, Pak } \\
\text { Suzuki Motors, } \\
\text { Indus Motors, } \\
\text { Honda Atlas Cars } \\
\text { and Dewan } \\
\text { Farooq Motors }\end{array}$ \\
\hline
\end{tabular}

Source: Engineering Development Board of Pakistan

Table 2: IJVs in Pakistan's automotive industry

\begin{tabular}{ll}
\hline IJVs (Foreign/local partner) & Major Products \\
\hline $\begin{array}{l}\text { Indus Motor Company } \\
\text { (Toyota, Japan and Daihatsu, Japan/ } \\
\text { House of Habib, Pakistan) }\end{array}$ & Toyota and Daihatsu Cuore cars \\
$\begin{array}{l}\text { Atlas Honda Ltd. } \\
\text { (Honda, Japan/ Atlas Group, Pakistan) }\end{array}$ & Civic, Accord, and City cars \\
$\begin{array}{l}\text { Pak Suzuki } \\
\text { (Suzuki, Japan/ Pakistan Automobile Corporation ) }\end{array}$ & Mehran, Baleno, and Cultus cars \\
\hline
\end{tabular}


Table 3: Interviewees' profiles

\begin{tabular}{lcc}
\hline \multicolumn{1}{c}{ Job Title } & $\begin{array}{c}\text { Number of } \\
\text { Interviewees }\end{array}$ & $\begin{array}{c}\text { Number of Years in Current } \\
\text { Position }\end{array}$ \\
\hline President/CEO & 15 & 16 \\
Senior Vice President & 4 & 10 \\
Deputy Managing Director & 15 & 8 \\
Operations Manager & 7 & 8 \\
Manager of Product Development & 4 & 7 \\
Technical Director & 5 & 9 \\
\hline
\end{tabular}


Table 4: Identified key themes and illustrative quotes

\begin{tabular}{|c|c|c|}
\hline Key themes & $\begin{array}{c}\text { Case } \\
\text { firms }\end{array}$ & Illustrative quotes \\
\hline $\begin{array}{l}\text { BS: assemblers initiate the } \\
\text { dialogue with global tier } 1 \\
\text { suppliers thus acting as } \\
\text { boundary spanners. }\end{array}$ & $\begin{array}{l}\text { Supplier } \\
\text { firm } 21\end{array}$ & $\begin{array}{l}\text { "Our clients are willing to initiate the technology } \\
\text { transfer dialogue with their first-tier suppliers in } \\
\text { Japan and elsewhere in the world." }\end{array}$ \\
\hline $\begin{array}{l}\text { BS: facilitators of the } \\
\text { transfer of technology from } \\
\text { global tier } 1 \text { suppliers. }\end{array}$ & $\begin{array}{l}\text { Supplier } \\
\text { firm } 5\end{array}$ & $\begin{array}{l}\text { "The assemblers are happy to transfer low-to- } \\
\text { medium complexity parts technology to us but for } \\
\text { advanced part technology they want us to form } \\
\text { joint ventures with their tier } 1 \text { suppliers based in } \\
\text { Japan and other countries." }\end{array}$ \\
\hline $\begin{array}{l}\text { BS: assemblers initiate } \\
\text { process of technology } \\
\text { transfer from their tier } 1 \\
\text { suppliers. }\end{array}$ & $\begin{array}{l}\text { Supplier } \\
\text { firm } 19\end{array}$ & $\begin{array}{l}\text { "The assembler played an initiator and facilitator } \\
\text { role in this transfer. All our communications and } \\
\text { agreements took place with the help of our } \\
\text { client." }\end{array}$ \\
\hline $\begin{array}{l}\text { SC: trust and long-term } \\
\text { relationship leverage - } \\
\text { boundary spanners. }\end{array}$ & $\begin{array}{l}\text { Supplier } \\
\text { firm } 2\end{array}$ & $\begin{array}{l}\text { "The assemblers have trusting relationships with } \\
\text { their global suppliers and they have been working } \\
\text { with them for a long time, so this relationship } \\
\text { leverage has been helpful in getting the key } \\
\text { technological knowledge from tier } 1 \text { suppliers in } \\
\text { Japan, and we have successfully collaborated } \\
\text { through the help of the assembler." }\end{array}$ \\
\hline $\begin{array}{l}\text { BS: linking up with the } \\
\text { global suppliers' networks } \\
\text { - boundary spanners. }\end{array}$ & $\begin{array}{l}\text { Supplier } \\
\text { firm } 8\end{array}$ & $\begin{array}{l}\text { "With the help of our assemblers, we were able to } \\
\text { form technical collaborations with one of the } \\
\text { leading Japanese suppliers ... Without this help } \\
\text { from the assembler, we wouldn't have been able } \\
\text { to close the deal." }\end{array}$ \\
\hline $\begin{array}{l}\text { BS \& SC: facilitator and } \\
\text { mediator in technology } \\
\text { transfer from tier } 1 \\
\text { suppliers, and trust. }\end{array}$ & $\begin{array}{l}\text { Supplier } \\
\text { firm } 13\end{array}$ & $\begin{array}{l}\text { "We are dealing with our assemblers that have } \\
\text { established relationships with their international } \\
\text { suppliers. As you know, it is difficult to gain } \\
\text { access to knowledge if the other party doesn't } \\
\text { trust you. Our assemblers have acted as key } \\
\text { facilitators and mediators between our firm and } \\
\text { their Japanese suppliers, using their relationships } \\
\text { with them." }\end{array}$ \\
\hline SC: trust-based relationship & $\begin{array}{l}\text { Supplier } \\
\text { firm } 17\end{array}$ & $\begin{array}{l}\text { "To bring knowledge from other firms and } \\
\text { especially associated network suppliers, the } \\
\text { assembler's trust-based relationship has been a } \\
\text { good way to enter into technical agreements with } \\
\text { tier } 1 \text { suppliers from Japan." }\end{array}$ \\
\hline $\begin{array}{l}\text { SC: socialization activities } \\
\text { for knowledge transfer }\end{array}$ & $\begin{array}{l}\text { Supplier } \\
\text { firm } 25\end{array}$ & $\begin{array}{l}\text { "In our case, we have visited Japanese suppliers' } \\
\text { plants, and their staff have been visiting our } \\
\text { facilities on a continuous basis to help us achieve }\end{array}$ \\
\hline
\end{tabular}




\begin{tabular}{|l|l|l|}
\hline SC: social ties & & a smooth transfer." \\
\hline $\begin{array}{l}\text { BS: assemblers' boundary- } \\
\text { spanning role. }\end{array}$ & $\begin{array}{l}\text { Secretary } \\
\text { firm 29 } \\
\text { (MOI\&P) }\end{array}$ & $\begin{array}{l}\text { "Our assembler has good social relationships } \\
\text { with the global systems suppliers and, through } \\
\text { their relationships, they have linked us with their } \\
\text { system suppliers." }\end{array}$ \\
$\begin{array}{l}\text { have helped many of our local suppliers in } \\
\text { negotiating technology transfers from their global } \\
\text { suppliers, because without the help of these three } \\
\text { IJVs (assemblers), global first-tier suppliers are } \\
\text { reluctant to join hands with the Pakistani } \\
\text { suppliers." }\end{array}$ \\
\hline $\begin{array}{l}\text { BS: boundary-spanning } \\
\text { role }\end{array}$ & Assembler & $\begin{array}{l}\text { "Using our relationship leverage, we acted as a } \\
\text { facilitator in linking up our local Pakistani } \\
\text { suppliers with our first-tier suppliers in Japan." }\end{array}$ \\
\hline $\begin{array}{l}\text { BS \& SC: facilitator and } \\
\text { mediator, utilizing trust and } \\
\text { durability of relationships } \\
\text { with tier 1 suppliers. }\end{array}$ & Assembler & $\begin{array}{l}\text { "Our firm has played an important role as a } \\
\text { facilitator and mediator of technology transfer to } \\
\text { Pakistan-based suppliers. As you can see, we } \\
\text { have a good business relationship based on } \\
\text { mutual trust, and durable relationships with our } \\
\text { tier 1 suppliers in Japan and elsewhere in the } \\
\text { world." }\end{array}$ \\
\hline
\end{tabular}

Note: BS: boundary spanner, SC: social capital, MOI\&P: Pakistan's Ministry of Industries and Production

Table 5: Pakistani component suppliers' technical collaborations

\begin{tabular}{ll}
\hline Components & Collaborating Partners \\
\hline Shock absorbers & Showa, Kayaba, Japan \\
Radiators & U.E. Radiators, Tokyo Radiator, Japan \\
Car A/C & Sanden, Denso, Japan \\
Radio cassette player & Panasonic Thailand \\
Lamps & Koito, Japan \\
Spark plugs & NGK, Japan \\
Glass & NGS, Japan \\
Steering case set & I.S. Seiseki, Japan \\
Brake drum assembly & Nissin Kogyo, Japan \\
Wiring harness & Furukawa, Japan; Yujin Electric System, Republic \\
& of Korea \\
\hline
\end{tabular}

Source: Authors' Interviews 


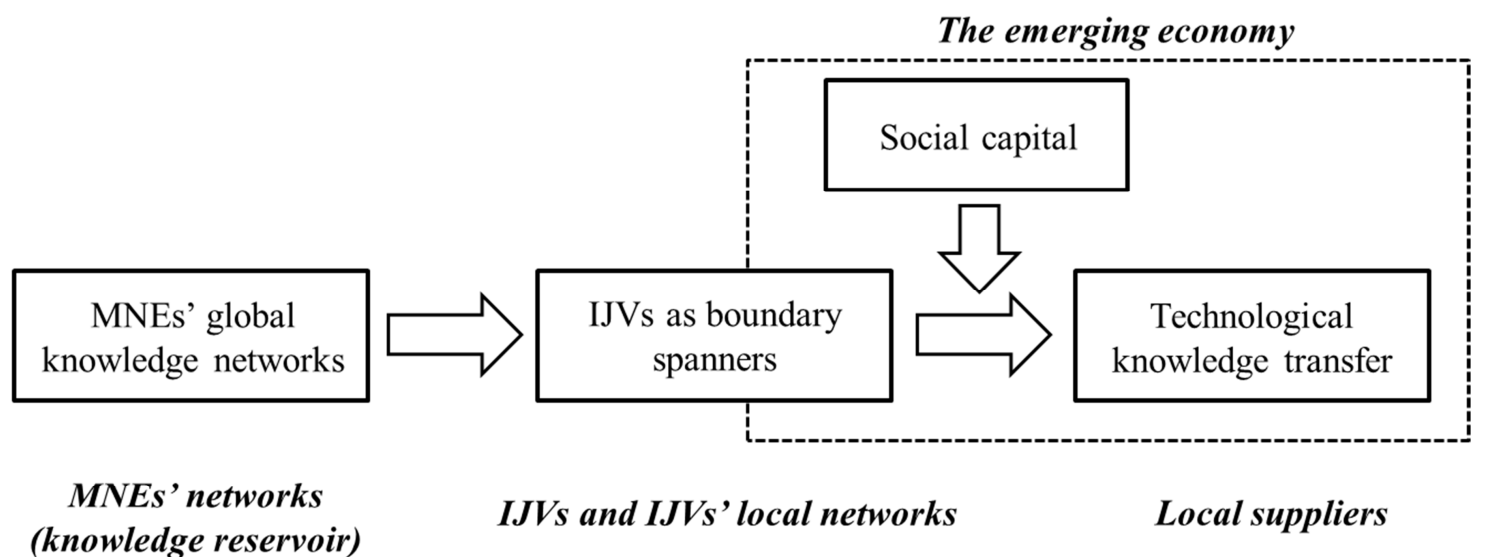

Figure 2: IJVs as boundary spanners of global knowledge transfer to local firms in the emerging economies 